\title{
Effects of a High-Intensity Interval Training Program on Body Composition and Physical Fitness in Female Field Hockey Players
}

\author{
Efectos de un Programa de Entrenamiento Intervalado de Alta Intensidad sobre \\ la Composición Corporal y Condición Física en Jugadoras de Hockey Césped
}

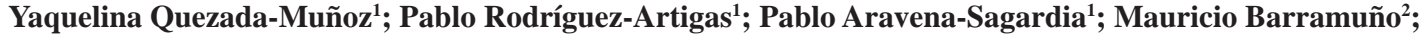 \\ Tomás Herrera-Valenzuela ${ }^{3,4}$; Eduardo Guzmán-Muñoz ${ }^{5}$; Braulio Henrique Magnani Branco ${ }^{6}$ Pablo Valdés-Badilla ${ }^{7,8}$
}

QUEZADA-MUÑOZ, Y.; RODRÍGUEZ-ARTIGAS, P.; ARAVENA-SAGARDIA, P.; BARRAMUÑO, M.; HERRERAVALENZUELA, T.; GUZMÁN-MUÑOZ, E.; MAGNANI, B. B. H. \& VALDÉS-BADILLA, P. Effects of a high-intensity interval training program on body composition and physical fitness in female field hockey players. Int. J. Morphol., 39(5):1323-1330, 2021.

SUMMARY: High-intensity interval training (HIIT) is zed by achieving similar effects to conventional physical and physiological training in a shorter time, allowing its dissemination in the sports field. The present study was aimed to analyze the effects of a HIIT program on body composition and general and specific physical fitness in Chilean female field hockey players. Experimental, repeated measures, simple blind, parallel groups, and a quantitative approach were used. The participants were randomized, and distributed into a control group $(\mathrm{CG} ; \mathrm{n}=10)$ that maintained regular field hockey training and an experimental group (EG; $n=10)$ that also received complementary training with HIIT. Body composition (muscle mass and adipose mass), general physical fitness (jump performance with countermovement jump [CMJ] and maximum oxygen consumption [VO2max] were evaluated with the test Course-Navette), and specific physical fitness (pushing speed, dribbling speed, and shooting accuracy) were assessed with established protocols. Pre- and post-intervention comparisons were made with Student's $t$ and Wilcoxon tests, considering $\mathrm{p}<0.05$. The main results indicate that the EG presented a significant increase in muscle mass $(p=0.024 ; d=0.62)$, CMJ $(p=0.005 ; d=1.10)$, VO2max $(p=0.001 ; d=1.58)$ and a significant reduction in adipose mass $(p=0.023 ; d=0.36)$ and time in pushing speed $(p=0.028 ; d=0.79)$. The CG did not present significant changes in any of the variables analyzed, and no significant differences were reported between the groups. In conclusion, eight weeks of HIIT significantly increases muscle mass, jump performance, and VO2max and significantly reduces adipose mass and time in pushing speed in Chilean female field hockey players.

KEY WORDS: Anthropometry; Exercise; Athletic Performance; Hockey; Women.

\section{INTRODUCTION}

Researchers' interest in high-intensity interval training (HIIT) has increased (Schaun et al., 2019). HIIT is zed by achieving shorter time effects like conventional training at a physical and physiological level in adult women (Funch $e t$ al., 2017). For this reason, various studies that have used HIIT programs suggest that its benefits are explained by the execution of high-intensity exercises (between $85 \%$ and 100 $\%$ of the maximum heart rate) and short duration with active or passive rest periods (Girard et al., 2018; Sarkar et al., 2019).
In the sports field, HIIT has been used frequently to stimulate physical fitness through exercises that involve speed, agility, cardio respiratory capacity, maximum strength, explosive strength, and flexibility (Schaun et al.) a fact that has favoured its use as a complementary training system in various sports specialties, achieving improvements in the physical and sports performance of athletes (Naimo et al., 2015; Funch et al.). Kinnunen et al. (2019) reported a significant increase in muscle mass and explosive strength in ice hockey players from Finland after a five-session

\footnotetext{
${ }^{1}$ Pedagogía en Educación Física. Facultad de Educación. Universidad Autónoma de Chile. Temuco, Chile.

${ }^{2}$ Carrera de Kinesiología, Facultad de Salud. Universidad Autónoma de Chile. Temuco, Chile.

${ }^{3}$ Escuela de Ciencias de la Actividad Física y Deportes. Facultad de Salud. Universidad Santo Tomás, UST, Chile.

${ }^{4}$ Universidad de Santiago de Chile(USACH), Escuela de Ciencias de la Actividad Física, el Deporte y la Salud, Chile.

${ }^{5}$ Escuela de Kinesiología. Facultad de Salud. Universidad Santo Tomás. Talca, Chile.

${ }^{6}$ Graduate Program in Health Promotion. Universidade Cesumar (UniCesumar), Maringá, PR, Brazil.

${ }^{7}$ Departamento de Ciencias de la Actividad Física. Facultad de Ciencias de la Educación. Universidad Católica del Maule. Talca, Chile.

${ }^{8}$ Carrera de Entrenador Deportivo, Escuela de Educación. Universidad Viña del Mar, Chile.
} 
QUEZADA-MUÑOZ, Y.; RODRÍGUEZ-ARTIGAS, P.; ARAVENA-SAGARDIA, P.; BARRAMUÑO, M.; HERRERA-VALENZUELA, T.; GUZMÁN-MUÑOZ, E.; MAGNANI, B. B. H. \& VALDÉS-BADILLA, P. Effects of a high-intensity interval training program on body composition and physical fitness in female field hockey players. Int. J. Morphol., 39(5):1323-1330, 2021

intervention with HIIT. Similarly, other studies have shown that HIIT-based programs achieve significant increases in maximum oxygen consumption ( $\mathrm{VO}_{2}$ max) in basketball and field hockey players (Sarkar et al.; Aschendorf et al., 2019), in the muscle mass of soccer players (Lee et al., 2020) and the explosive strength of handball players (ViañoSantasmarinas et al., 2018). Similarly, HIIT programs with exercises related to the characteristics of sports disciplines have reported beneficial results in athletes (Aschendorf et $a l$; Lee et al.). For example, in soccer players, significant improvements have been reported in muscle strength and muscle power (Lee et al.), while in basketball players, improvements have occurred in $\mathrm{VO} 2 \mathrm{max}$, speed, and agility (Aschendorf et al.).

Field hockey players require high cardio respiratory capacity, endurance, and muscular power due to the game demands that involve constant changes in speed and direction (Sarkar et al.; Funch et al.). Considering all the above, this study aims to analyze the effects of a HIIT program on body composition, and general (jump performance and VO2max) and specific physical fitness (pushing speed, dribbling speed, and shooting accuracy) in Chilean female field hockey players. Considering the reports of previous studies (Sarkar et al.; Naimo et al.; Funch et al.), it is hypothesized that eight weeks of HIIT produces a significant increase in muscle mass, jump performance, VO2max, dribbling speed, and shooting accuracy, as well as a significant reduction in fat mass and pushing speed in female field hockey players.

\section{MATERIAL AND METHOD}

Design. An experimental, randomized, single-blind, repeated measures, parallel groups, and quantitative approach was used. The participants were selected through proportional and random sampling (https://www.randomizer.org), distributed betweena control group $(\mathrm{CG} ; \mathrm{n}=10)$ that maintained regular field hockey training and an experimental group (EG; $n=10)$ who also received supplementary HIIT for eight weeks (16 sessions) in the form of a 14-min workout, distributed between seven exercises of one-min of work and one-min of rest at the end of each session (All-out mode), considering a ratio of 1:1 work and rest.

Participants. The population corresponds to a field hockey club in Temuco, Chile $(n=20)$. The inclusion criteria used were: i) >18 years old and an active member of the club; ii) have participated in the national field hockey league for more than 6 months; iii) have played at least half of the games of the 2019 season (12 games); and iv) reached at least $85 \%$ attendance at training. The following were excluded: i) those women who had musculoskeletal injuries or were undergoing physical rehabilitation treatment that impeded their normal physical performance; ii) those who have permanent or temporary contraindications to physical activity, and iii) participants who perform in the position of goalkeeper. Finally, there were 10 players in the EG (age $23.6+2.8$ years and bipedal height $158.3+5.0 \mathrm{~cm}$ ) and 6 players in the CG (age $23.6+3.0$ years and bipedal height $163.3+6.8$ $\mathrm{cm})$. No injuries were reported, while the CG withdrawals were due to individuals not attending the second assessment. In Figure 1, a graphical description of the randomization process of the participants is presented.

All participants were informed of the scope of the study and signed an informed consent that authorises the use of the information for scientific purposes. The research protocol was reviewed and approved by the Scientific Ethics Committee of the Universidad Autónoma de Chile (No. 12618) and was developed following the provisions of the Declaration of Helsinki.

Body composition. The study began with measuring body weight using a digital scale (Scale-tronix, USA; accuracy: $0.1 \mathrm{~kg}$ ), while bipedal height was measured with a stadiometer (Seca model 220, Germany; accuracy: $0.1 \mathrm{~cm}$ ). All measurements were performed following the recommendations of the International Society for Advances in Kineanthropometry (ISAK) (Marfell-Jones et al., 2012). Then, six diameters were evaluated (biacromial, transverse thorax, anteroposterior thorax, bilio crystal, humeral, femoral), ten perimeters (head, arm relaxed, arm flexed in tension, forearm maximum, mesosternal chest, minimum waist, maximum hip, maximum thigh, medial thigh, maximum calf) and six skinfolds (tricipital, subscapular, supraspinal, abdominal, medial thigh, calf), by a level II anthropometrist (technical measurement error: $0.8 \%$ for all variables evaluated) of the ISAK. Using the indirect pentacompartmental fractionation technique proposed by Ross \& Kerr (1993), all participants' muscle mass and adipose mass were determined using the same pre-and postintervention anthropometric model. In addition, the body mass index (BMI) of each participant was calculated by dividing the body weight in $\mathrm{kg}$ by the bipedal height in $\mathrm{m}^{2}$.

\section{General physical fitness assessments}

Jump performance. This was determined through the Counter Movement Jump (CMJ) test using a force platform (Art Oficio, PF-4000/50; Chile) as a direct indicator of lower body strength (Bosco et al., 1983). During the execution of the test, each participant was in a standing position, feet aligned at the width of the shoulders, extended knees, hands on the waist, and then made a quick vertical jump, performing a knee flexion-extension until 


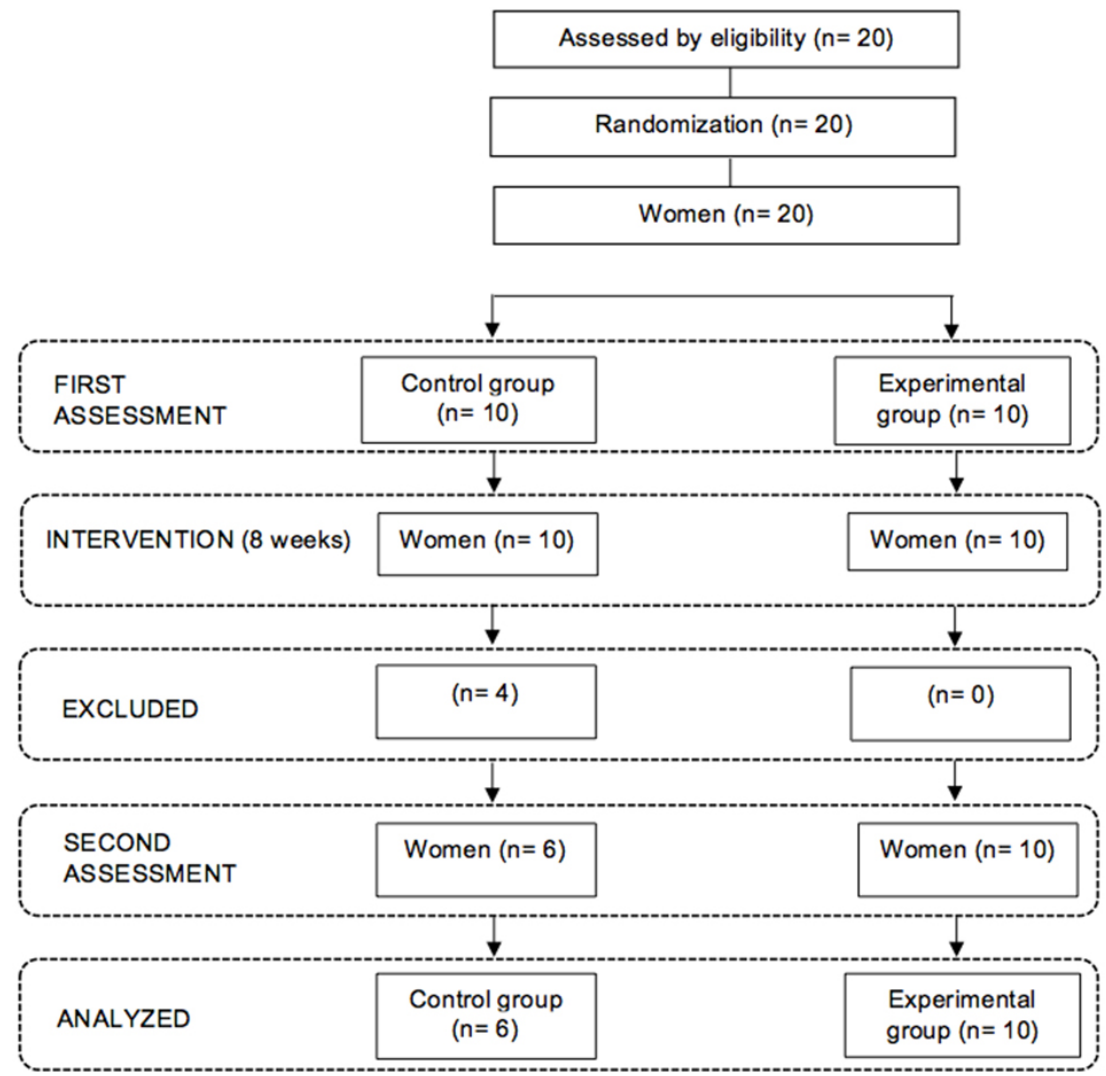

Fig. 1. Flow chart of the process followed in the research.

reaching a $90^{\circ}$ angle. The participants performed a previous warm-up on a cycle ergometer and then performed three repetitions of the CMJ with rest of one min. between each jump, being considered the maximum height for subsequent analyses (Bosco et al.).

Maximum oxygen consumption (VO2max). This was calculated using the test Course-Navette, one of the most widely used and reliable tests to indirectly obtain $\mathrm{VO} 2 \mathrm{max}$ in athletes (García \& Secchi, 2014). The procedure to determine the VO2max was as follows: i) the participants had to run as long as possible between two lines separated by $20 \mathrm{~m}$ (round trip), where a sound signal imposed the race pace; ii) the first stages were at a low speed, and their objective was to familiarise the participants with the test and, in turn, carry out a specific warm-up; iii) the speed started at $8.5 \mathrm{~km} / \mathrm{h}$ and increased by $0.5 \mathrm{~km} / \mathrm{h}$ every min; iv) the participants had to cross each line (located at $20 \mathrm{~m}$ ) at the exact moment when the sound signal was emitted; and v) the test ended when the participants stopped or failed to cross any of the lines on two consecutive occasions at the time of the sound signal (García \& Secchi). The formula to obtain the VO2max was as follows (García \& Secchi):
$\mathrm{VO}_{2} \max =(6 \mathrm{xV})-27.4$. Where $\mathrm{V}$ is the speed reached.

Specific physical fitness assessments. To obtain the specific performance of the participants, the protocols proposed by Keogh et al. (2003) for field hockey players were followed. This consisted of three measured:

Pushing speed. The pushing speed was estimated by recording the time it takes for a hockey ball moved by a stick to travel $10 \mathrm{~m}$. For this test, the participants were located at the court's bottom line, $20 \mathrm{~m}$ from them were two cones (A), and $10 \mathrm{~m}$ from these were two more cones (B). The players performed a push passing the ball between cones $\mathrm{A}$ and $\mathrm{B}$. The execution time was recorded in seconds; after three attempts, the best time was considered for the assessments (Keogh et al.).

Dribbling speed. This was measured in two stages, one through the traditional version of the Illinois Agility Run (IAR), and the other through its adapted version (IAR-D). Said measures were carried out with a stick and ball. It was carried out in a $10 \mathrm{~m}$ long by $5 \mathrm{~m}$ wide marked by cones; starting at the evaluator's signal, the participants followed the already defined route at maximum speed, 
QUEZADA-MUÑOZ, Y.; RODRÍGUEZ-ARTIGAS, P.; ARAVENA-SAGARDIA, P.; BARRAMUÑO, M.; HERRERA-VALENZUELA, T.; GUZMÁN-MUÑOZ, E.; MAGNANI, B. B. H. \& VALDÉS-BADILLA, P. Effects of a high-intensity interval training program on body composition and physical fitness in female field hockey players. Int. J. Morphol., 39(5):1323-1330, 2021

being timed on both occasions. To establish the percentage difference between IAR vs. IAR-D, the following formula was used (Keogh et al.):

Percentage difference $=[($ IAR $-\mathrm{D})-(\mathrm{IAR})] /$ IAR x 100

Shooting accuracy. This test was carried out within the goal area. Each player had eight shots executed from five different positions, previously established, in the direction of the goal; four shots were hit from positions 1 to 4 , two were pushed from positions 2 and 3, and two flick shots were taken from position 5 . Each shot made was given 1 point, and failed shots were given 0 , ranging from 0 to 8 points. No speed or strength was required by the participants (Keogh et al.).

Intervention. In the first meeting, the players were interviewed and informed about the scope of the study. Then, in the first week, the players were measured in three sessions: the first contemplated body composition and jump performance; the second session was the test CourseNavette; and the third session considered specific physical fitness assessments (pushing speed, dribbling speed, and shooting accuracy). After the initial assessments, the EG players participated in a HIIT program that lasted for eight weeks (16 sessions), which was carried out at the end of each regular hockey training session. The seven exercises were divided into two actions with an emphasis on the lower body (jump squats and tuck jumps), two with emphasis on the upper body (push-ups and diamond pushups), and three exercises with emphasis on the core (mountain climbers, plank and jump mountain climbers). The volume and intensity of the training remained constant. The summary of the intervention and order of the exercises can be seen in Figure 2.

Statistical analysis. The SPSS (Statistical Package for the Social Sciences) program, version 25.0, was used for data analysis. The variables were subjected to the Shapiro-Wilk normality test, Levene's homogeneity of variance, and descriptive analysis to obtain the arithmetic mean, standard deviation of the data, and $95 \%$ confidence interval. Pre-and post-intervention changes were with Student's t ttest when the variables were regular, and the Wilcoxon test was not. The student's t-test for independent samples was used for comparison between groups. The effect size (ES) was calculated with Cohen's d (Cohen, 1992), considering a small (0.20-0.49), moderate (0.50-0.79), or strong effect $(>0.80)$. In all cases, a significance value of $\mathrm{p}<0.05$ was established.

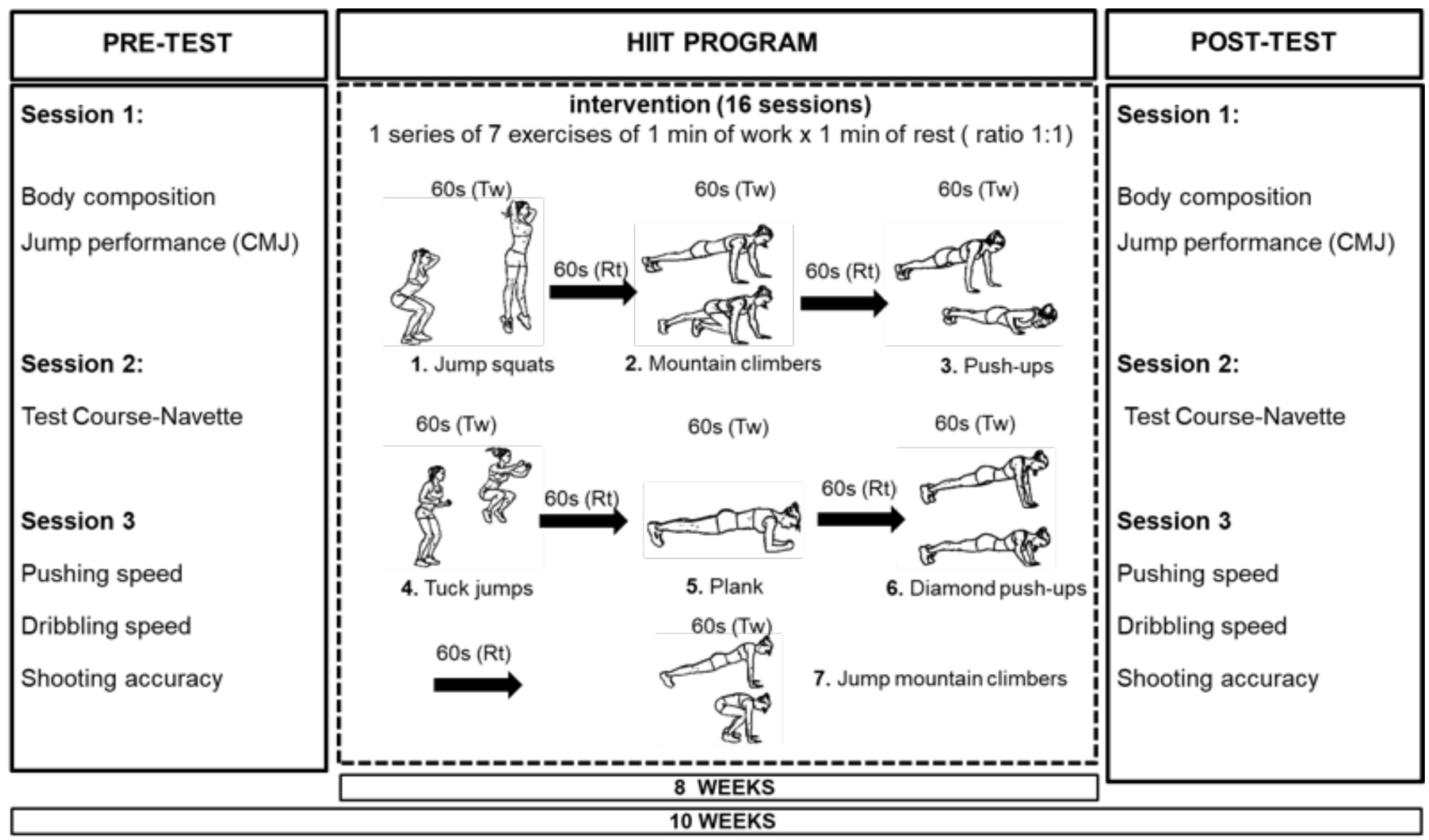

Fig. 2. Study design. 


\section{RESULTS}

Table I shows that only EG shows a significant increase in muscle mass $(\mathrm{p}=0.024)$ with a moderate ES $(\mathrm{d}=0.62)$ and a significant reduction in adipose mass $(\mathrm{p}$ $=0.023)$ with a small ES $(\mathrm{d}=0.36)$. In contrast, the CG did not present significant changes in body composition. Comparisons between the groups did not report significant differences.

Table II shows the performance in the general and specific physical fitness assessments of the evaluated players. The EG reported a significant increase in jump performance measured through the $\mathrm{CMJ}(\mathrm{p}=0.005)$ with a strong ES $(\mathrm{d}=1.10), \mathrm{VO} 2 \mathrm{max}$ increased significantly $(p=0.001)$ with a strong ES $(d=1.58)$, and time in pushing speed showed a significant reduction $(\mathrm{p}=0.028)$ with a moderate ES $(d=0.79)$. For its part, the CG did not show significant changes in general and specific physical fitness. Furthermore, the comparisons between groups did not report significant differences between the groups.

Table I. Effect of the HIIT program on the body composition of the female field hockey players.

\begin{tabular}{|c|c|c|c|c|c|c|c|}
\hline & & $\begin{array}{c}\text { Pre-test } \\
\text { Mean (SD) }\end{array}$ & $\begin{array}{c}\text { Post-test } \\
\text { Mean (SD) }\end{array}$ & $p$ value & $\Delta$ absolute & $\begin{array}{c}\Delta \text { relative } \\
(\%)\end{array}$ & $d(\mathrm{CI} 95 \%)$ \\
\hline \multirow[t]{2}{*}{ Body weight $(\mathrm{kg})$} & CG & $67.80(17.33)$ & $69.20(20.91)$ & 0.58 & 1.4 & 2.06 & $0.40(-6.12 / 3.12) \pi$ \\
\hline & EG & $62.20(5.92)$ & $61.60(4.60)$ & 0.67 & -0.6 & -0.96 & $0.15(-2.00 / 3.10)$ \\
\hline \multirow[t]{2}{*}{ BMI $\left(\mathrm{kg} / \mathrm{m}^{2}\right)$} & CG & $26.20(4.21)$ & $26.00(5.61)$ & 0.78 & -0.2 & -0.76 & $0.13(-2.61 / 3.21)$ \\
\hline & EG & $25.60(2.67)$ & $24.70(0.95)$ & 0.23 & -0.9 & -3.52 & $0.53(-0.39 / 2.55)^{\circ}$ \\
\hline \multirow[t]{2}{*}{ Fat mass $(\%)$} & CG & $35.80(5.72)$ & $34.80(3.27)$ & 0.46 & -1 & -2.79 & $0.37(-2.40 / 4.40) \llbracket$ \\
\hline & EG & $34.70(5.14)$ & $33.70(4.62)$ & 0.02 & -1 & -2.88 & $0.87(0.17 / 1.83)^{\dagger}$ \\
\hline \multirow[t]{2}{*}{ Muscle mass (\%) } & CG & $37.00(4.06)$ & $38.20(2.49)$ & 0.24 & 1.2 & 3.24 & $0.62(-3.59 \text { a } 1.19)^{\circ}$ \\
\hline & EG & $38.20(4.54)$ & $39.40(4.27)$ & 0.02 & 1.2 & 3.14 & $0.86(-2.20$ a -0.20$)$ \\
\hline
\end{tabular}
moderate effect. $\dagger=$ strong effect.

Table II. Effect of the HIIT program on the general and specific physical fitness of the female field hockey players.

\begin{tabular}{|c|c|c|c|c|c|c|c|}
\hline & & $\begin{array}{c}\text { Pre-test } \\
\text { Mean (SD) }\end{array}$ & $\begin{array}{l}\text { Post-test } \\
\text { Mean (SD) }\end{array}$ & $p$ value & $\Delta$ absolute & $\Delta$ relative $(\%)$ & $d(\mathrm{CI} 95 \%)$ \\
\hline \multirow[t]{2}{*}{$\mathrm{CMJ}(\mathrm{cm})$} & GC & $19.11(4.17)$ & $21.67(5.32)$ & 0.116 & 2.56 & 13.40 & $0.92(-5.33 / 0.45) \dagger$ \\
\hline & GE & $19.60(4.40)$ & $23.30(5.64)$ & 0.005 & 3.70 & 18.88 & $1.1(-6.17 /-1.31)^{\dagger}$ \\
\hline $\mathrm{VO}_{2}$ & $\mathrm{GC}$ & $35.25(5.50)$ & $37.13(4.79)$ & 0.140 & 1.88 & 5.33 & $0.73(-4.54 / 0.79)^{\circ}$ \\
\hline$(\mathrm{ml} / \mathrm{kg})$ & GE & $37.50(6.04)$ & $40.20(5.14)$ & 0.001 & 2.70 & 7.20 & $1.59(-3.92 /-1.48)^{\dagger}$ \\
\hline \multirow[t]{2}{*}{$\mathrm{DS} \quad(\%)$} & GC & $34.56(18.13)$ & $35.67(12.85)$ & 0.788 & 1.11 & 3.21 & $0.21(-10.54 / 8.05)^{\mathrm{I}}$ \\
\hline & GE & $30.20(11.41)$ & $28.20(7.60)$ & 0.530 & -2.00 & -6.62 & $0.17(-5.24 / 8.54)$ \\
\hline \multirow[t]{2}{*}{ PS $\quad(\mathrm{m} / \mathrm{s})$} & $\mathrm{GC}$ & $2.15(1.33)$ & $1.92(0.97)$ & 0.260 & -0.20 & -10.70 & $0.55(-0.12 / 0.57)^{\circ}$ \\
\hline & GE & $2.56(1.41)$ & $1.91(0.79)$ & 0.028 & -0.65 & -25.39 & $0.79(0.06 / 1.23)^{\circ}$ \\
\hline \multirow[t]{2}{*}{$\mathrm{SA} \quad(\%)$} & GC & $1.44(1.33)$ & $1.56(1.42)$ & 0.760 & 0.12 & 8.33 & $0.53(-0.92 / 0.70)^{\circ}$ \\
\hline & GE & $2.30(1.49)$ & $2.60(1.84)$ & 0.193 & 0.30 & 13.04 & $0.44(-0.78 / 0.18)^{\mathbb{I}}$ \\
\hline
\end{tabular}

CMJ: countermovement jump. VO2 max: Maximum oxygen consumption. DS: dribling speed. PS: pushing speed. SA: shooting accuracy. SD: standard deviation. d: effect size. CG: control group. EG: experimental group. CI: confidence interval. $\mathbb{I I}=$ small effect. ${ }^{\circ}=$ moderate effect. $\dagger=$ strong effect.

\section{DISCUSSION}

This study aimed to analyze the effects of a HIIT program on body composition and general and specific physical fitness in Chilean female field hockey players. The main results indicate that field hockey players achieve a significant increase in muscle mass, jump performance, and VO2max, and a significant reduction in adipose mass and time in pushing speed after 16 complementary sessions with HIIT. This strengthens the scientific literature that reports 
QUEZADA-MUÑOZ, Y.; RODRÍGUEZ-ARTIGAS, P.; ARAVENA-SAGARDIA, P.; BARRAMUÑO, M.; HERRERA-VALENZUELA, T.; GUZMÁN-MUÑOZ, E.; MAGNANI, B. B. H. \& VALDÉS-BADILLA, P. Effects of a high-intensity interval training program on body composition and physical fitness in female field hockey players. Int. J. Morphol., 39(5):1323-1330, 2021

significant improvements like those reported by our study at the level of body composition and physical fitness in female handball athletes after 6 weeks of HIIT (ViañoSantasmarinas et al.) and coinciding with improvements reported for $\mathrm{VO} 2 \mathrm{max}$ level in field hockey players, after four weeks of HIIT (Funch et al.).

Body composition presented significant changes only in EG; specifically, a significant increase in muscle mass and a significant reduction in adipose mass were reported. This is consistent with previous studies reporting similar results after four weeks of HIIT in female ice hockey players (Naimo et al.) and eight weeks in male field hockey players (Sarkar et al.). The increase in muscle mass of the EG in our study was like that of Lee et al., who reported a significant increase in muscle mass in soccer players after 15 sessions of HIIT, in addition to achieving a thickening of the crosssection of the quadriceps. This could be explained by the increase in muscle protein synthesis, resulting in morphological adaptations in the size of muscle fibers (Moghaddam et al., 2020). On the other hand, it has been pointed out that HIIT produces bidirectional changes in muscle fibers, especially in type I and IIa (Sarkar et al.). These facts could favour the increase in glycogen consumption due to the high intensity and short duration exercises typical of the HIIT, producing an effect like muscle hypertrophy training in these variables (Hearris et al., 2018).

Fat mass was significantly reduced in EG only. This situation was similar to that reported by Fernandez et al. (2017), who, after 16 sessions of HIIT, achieved a significant decrease in the percentage of fat mass in handball players. A recent meta-analysis reported that the HIIT programs correspond to an efficient strategy to reduce fat deposits at the abdominal and visceral level (Maillard et al., 2018). Changes at the level of adipose mass could be related to the increase in mitochondrial oxidative enzymes since these produce a breakdown and reduction of adipose tissue (Viñuela García et al., 2016). Another factor that could influence the decrease in adipose mass is the increase in catecholamines, a product of muscular stress when the body is subjected to exercises with high-intensity intervals with short rest periods, generating an increase in lipolysis involved in the combustion of fats, favouring the reduction of adipose mass (Maillard et al.). On the other hand, the reduction in body fat can also be related to the increase in energy expenditure provided by the training sessions, regardless of being classified as HIIT.

Regarding the jump performance (CMJ), a significant increase was reported only in the EG. Previous studies have shown an improvement in jump performance after participating in HIIT interventions that included exercises using body weight and multi-jumps in physically active young people (Schaun et al.) and in handball players (Fernández et al., 2017). In this sense, it has been shown that exercises that only use body weight as a training load, accompanied by multi-jumps, show an improvement in jump performance due to greater stimulation of the neuromuscular system, which produces an increase in muscle power and explosive strength of the lower body in athletes (Schaun et $a l$.). Consequently, the improvements exhibited by field hockey players in the $\mathrm{CMJ}$ could be attributed to the increase in muscular power of the lower body since the exercises selected for the intervention included actions with body weight and multi-jumps (Schaun et al.; Fernández et al.).

VO2max increased significantly in EG. Similarly, other authors reported a significant increase in VO2max after interventions with HIIT for four (Funch et al.) and eight weeks (Sarkar et al.) in field hockey players. The increase in VO2max could be related to central and peripheral factors, such as hypertrophy of the left ventricle, greater contractility of the cardiac muscles, and increased stroke volume, influenced by the exercises, work times, and rest selected in the intervention, which required high oxygen mobilization in a short time (Foster et al., 2015; Funch et al.; Sarkar et $a l$.). These facts could increase cardiac output, which favours peripheral adaptations that allow a greater capacity to extract and use available oxygen (Foster et al.; Sarkar et al.).

In terms of performance for specific physical fitness assessments, only a significant reduction in pushing speed was reported on the EG. The exercises selected for the intervention that mainly focused on the core could influence changes in pushing speed. This agrees with previous studies which refer to the posture adopted by field hockey players, which is more inclined than other sports disciplines, due to the trunk flexion acquired in the game (Lemos et al., 2017). This characteristic (posture) likely influenced the results of physical performance, a fact that agrees with those indicated by Lemos et al., who stated that there must be a high level of core training, especially to avoid vertebral injuries, due to the overload of the lumbar area. On the other hand, the important role that the core has in the human movement has been reported, helping to coordinate the actions of the trunk with the extremities to produce efficient actions, thereby affecting the generation, transfer, and control of forces or energies during activities of the integrated kinetic chain (Okada et al., 2011), which could result in better performance for specific sports actions.

On the other hand, the dribbling speed and shooting accuracy did not report significant CG or EG changes. For its part, dribbling speed requires a high degree of agility on the part of the players since hockey demands fast turns and 
acceleration (Sharma \& Kailashiya, 2018). In this sense, our HIIT program did not consider dribbling exercises or direction changes, which could have affected dribbling speed performance. This is reinforced by previous studies suggesting that agility is an independent motor skill and should be trained in isolation (Paul et al., 2016). Regarding shooting accuracy, which did not reveal significant changes in the evaluated groups, it is comparable with a study in soccer players for penalty kicks, which indicates that to obtain effective results in shooting accuracy, this action must be trained, since there are perceptual-motor and psychological variables that influence the result in a specific skill (Navia \& Ruiz, 2014). These facts could explain our results since the HIIT program did not consider exercises that stimulate shooting accuracy.

Among the possible limitations of the study are: i) not controlling diet, which could influence body composition, and general and specific physical fitness of the participants; ii) the small sample number, which limited the statistical analyses; and iii) not performing a sample size calculation, which limits the internal consistency and extrapolation of the data. The main strengths are i) the design of the study and the characteristics of the sample; ii) the simplicity of the assessments carried out that, with little training, could be used by coaches and trainers to measure the general and specific physical fitness of field hockey players; and iii) the planning and development of the HIIT program, which used exercises focused on the muscle groups most commonly used in field hockey and developed with one's body weight.

In conclusion, eight weeks of HIIT significantly increases muscle mass, jump performance, and VO2max and significantly reduces adipose mass and time in pushing speed in Chilean female field hockey players. Therefore, using HIIT programs as a complement to regular training can be an efficient alternative for general and specific physical preparation in women of this sport specialty.

QUEZADA-MUÑOZ, Y.; RODRÍGUEZ-ARTIGAS, P.; ARAVENA-SAGARDIA, P.; BARRAMUÑO, M.; HERRERAVALENZUELA, T.; GUZMÁN-MUÑOZ, E.; MAGNANI, B. B. H. \& VALDÉS-BADILLA, P. Efectos de un programa de entrenamiento intervalado de alta intensidad sobre la composición corporal y condición física en jugadoras de hockey césped. Int. J. Morphol., 39(5):1323-1330, 2021.

RESUMEN: El entrenamiento intervalado de alta intensidad (EIAI) se caracteriza por conseguir en un menor tiempo efectos similares al entrenamiento convencional a nivel físico y fisiológico, lo que ha permitido su difusión en el ámbito deportivo. El objetivo del presente estudio fue analizar los efectos de un progra- ma de EIAI sobre la composición corporal, condición física general y específica en mujeres chilenas que practican hockey césped. Estudio experimental, de medidas repetidas, simple ciego, grupos paralelos y enfoque cuantitativo. Las participantes fueron aleatorizadas y distribuidas en grupo control $(\mathrm{GC} ; \mathrm{n}=10)$ que mantuvo los entrenamientos regulares de hockey césped y grupo experimental (GE; n=10) que además recibió de complemento EIAI. Se evaluó la composición corporal (masa muscular y masa adiposa), condición física general (capacidad de salto con el salto contra movimiento [CMJ] y consumo máximo de oxígeno [VO2máx] con la prueba Course de Navette) y condición física específica (velocidad de empuje, velocidad de dribling y precisión de tiro) con protocolos establecidos. Se realizaron comparaciones pre y post intervención con las pruebas t de Student y Wilcoxon, considerando un $\mathrm{p}<0,05$. Los principales resultados indican que el GE presentó un aumento significativo de la masa muscular $(\mathrm{p}=0,024 ; \mathrm{d}=0,62), \mathrm{CMJ}$ $(\mathrm{p}=0,005 ; \mathrm{d}=1,10)$, VO2máx $(\mathrm{p}=0,001 ; \mathrm{d}=1,58)$ y, una reducción significativa, de la masa adiposa $(\mathrm{p}=0,023 ; \mathrm{d}=0,36)$ y del tiempo en la velocidad de empuje ( $\mathrm{p}=0,028 ; \mathrm{d}=0,79)$. El GC no presentó cambios significativos en ninguna de las variables analizadas, mientras que no se reportaron diferencias significativas entre los grupos. En conclusión, ocho semanas de EIAI aumentan significativamente la masa muscular, capacidad de salto y VO2máx, además de reducir significativamente la masa adiposa y el tiempo en la velocidad de empuje en mujeres chilenas que practican hockey césped.

PALABRAS CLAVE: Antropometría; Ejercicio; Rendimiento deportivo; Hockey; Mujeres.

\section{REFERENCES}

Aschendorf, P. F.; Zinner, C.; Delextrat, A.; Engelmeyer, E. \& Meste, J. Effects of basketball-specific high-intensity interval training on aerobic performance and physical capacities in youth female basketball players. Phys. Sportsmed., 47(1):65-70, 2019.

Bosco, C.; Luhtanen, P. \& Komi, P. V. A simple method for measurement of mechanical power in jumping. Eur. J. Appl. Physiol., 50(2):273-82, 1983.

Cohen, J. A power primer. Psychol. Bull., 112(1):155-9, 1992.

Fernández, A.; Lima Correa, F.; Gutierrez Sánchez, A \&, Abadía García de Vicuña, O. Effects of a high-intensity interval training protocol based on functional exercises on performance and body composition in handball female players. J. Hum. Sport Exerc., 12(4):1186-98, 2017.

Foster, C.; Farland, C.; Guidotti, F.; Harbin, M.; Roberts, B.; Schuette, J.; Tuuri, A.; Doberstein, S. T. \& Porcari, J. P. The effects of high intensity interval training vs steady state training on aerobic and anaerobic capacity. J. Sports Sci. Med., 14(4):747-55, 2015.

Funch, L. T.; Lind, E.; True, L.; Van Langen, D.; Foley, J. T. \& Hokanson, J. F. Four weeks of off-season training improves peak oxygen consumption in female field hockey players. Sports (Basel), 5(4):89, 2017.

García, G. C. \& Secchi, J. D. Test course navette de 20 metros con etapas de un minuto. Una idea original que perdura hace 30 años. Apunts Med. Esport, 49(183):93-103, 2014.

Girard, J.; Feng, B. \& Chapman, C. The effects of high-intensity interval training on athletic performance measures: a systematic review. Phys. Ther. Rev., 23(2):151-60, 2018.

Hearris, M. A.; Hammond, K. M.; Fell, J. M. \& Morton, J. P. Regulation of muscle glycogen metabolism during exercise: implications for endurance performance and training adaptations. Nutrients, 10(3):298, 2018 
Keogh, J. W. L.; Weber, C. L. \& Dalton, C. T. Evaluation of anthropometric, physiological, and skill-related tests for talent identification in female field hockey. Can. J. Appl. Physiol., 28(3):397-409, 2003.

Kinnunen, J. V.; Piitulainen, H. \& Piirainen, J. M. Neuromuscular adaptations to short-term high-intensity interval training in female icehockey players. J. Strength Cond. Res., 33(2):479-85, 2019.

Lee, K. H.; Lee, K. \& Choi, Y. C. Very short-term high intensity interval training in high school soccer players. Int. J. Men Health, 16(2):e1-e8, 2020.

Lemos, R. S.; Paz, G. A.; de Freitas Maia, M.; Baptista da Silva, J.; Lima, V. P.; Brandão Pinto de Castro, J. \& Miranda, H. Anthropometric and physical fitness parameters versus specific performance tests in Brazilian field hockey athletes: a pilot study. Biomed. Hum. Kinet., 9(1):57-63, 2017.

Maillard, F.; Pereira, B. \& Boisseau, N. Effect of high-intensity interval training on total, abdominal and visceral fat mass: a meta-analysis. Sports Med., 48(2):268-88, 2018.

Marfell-Jones, M. J.; Stewart, A. D. \& de Ridder, J. H. International Standards for Anthropometric Assessment. Wellington, International Society for the Advancement of Kinanthropometry, 2012. Available from: http://hdl.handle.net/11072/1510

Moghaddam, M.; Estrada, C. A.; Baghurst, T. \& Jacobson, B. H. Muscular morphological adaptations of two whole-body high intensity interval training configurations. J. Sports Med. Phys. Fitness, 60(7):985-91, 2020.

Naimo, M. A.; de Souza, E. O.; Wilson, J. M.; Carpenter, A. L.; Gilchrist, P.; Lowery, R. P.; Averbuch, B.; White, T. M. \& Joy, J. High-intensity interval training has positive effects on performance in ice hockey players. Int. J. Sports Med., 36(1):61-6, 2015.

Navia, J. A. \& Ruiz, L. M. Análisis de la complejidad perceptivo-motriz y psicológica del penalti en el fútbol. RICYDE Rev. Int. Cienc. Deporte, 10(37):264-80, 2014.

Okada, T.; Huxel, K. C. \& Nesser, T. W. Relationship between core stability, functional movement, and performance. J. Strength Cond. Res., 25(1):252-61, 2011

Paul, D. J.; Gabbett, T. J. \& Nassis, G. P. Agility in team sports: Testing, training and factors affecting performance. Sports Med., 46(3):421-42, 2016.

Ross, W. D. \& Kerr, D. A. Fraccionamiento de la Masa Corporal: Un Nuevo Método para Utilizar en Nutrición, Clínica y Medicina Deportiva. Ciudad de Córdoba, G-SE, 1993. Avaliable from: https://g-se.com/ fraccionamiento-de-la-masa-corporal-un-nuevo-metodo-para-utilizaren-nutricion-clinica-y-medicina-deportiva-261-sa-Q57cfb27120415

Sarkar, S.; Chatterjee, S. \& Dey, S. K. Effect of 8 weeks high intensity interval training on maximum oxygen uptake capacity and related cardio-respiratory parameters at anaerobic threshold level of indian male field hockey players. Eur. J. Phys. Educ. Sport Sci., 5(5):106-16, 2019.

Schaun, G. Z.; Pinto, S. S.; Brasil, B.; Nunes, G. N. \& Alberton, C. L. Neuromuscular adaptations to sixteen weeks of whole-body highintensity interval training compared to ergometer-based interval and continuous training. J. Sports Sci., 37(14):1561-9, 2019.

Sharma, H. B. \& Kailashiya, J. Effects of 6-week sprint-strength and agility training on body composition, cardiovascular, and physiological parameters of male field hockey players. J. Strength Cond. Res., 32(4):894-901, 2018.

Viaño-Santasmarinas, J.; Rey, E.; Carballeira, S. \& Padrón-Cabo, A. Effects of high-intensity interval training with different interval durations on physical performance in handball players. J. Strength Cond. Res., 32(12):3389-97, 2018.

Viñuela García, M.; Vera Ibáñez, A.; Colomer Poveda, D.; Márquez Sánchez, G. \& Romero Arenas, S. Efecto de 12 sesiones de un entrenamiento interválico de alta intensidad sobre la composición corporal en adultos jóvenes. Nutr. Hosp., 33(3):637-43, 2016.

\author{
Corresponding author: \\ Pablo Antonio Valdés Badilla \\ Universidad Católica del Maule \\ Av. San Miguel 3605 \\ Talca \\ CHILE
}

E-mail: valdesbadilla@gmail.com

Received: 07-05-2021

Accepted: 23-06-2021 